\title{
ADDENDUM AND ERRATUM
}

to the paper 'Thermal Evolution of the Moon', by M. Nafi Toksöz, Sean C. Solomon, John W. Minear, and David H. Johnston, The Moon 4 (1972), 190-213.

The heat flow values listed in Table I of the above paper are incorrect. A new table, given below, lists the original and the corrected heat flow values. New values of surface heat flow were calculated by adding the heat flow at the boundary between the upper two finite-difference cells to the steady-state heat flow due to heat production in the uppermost half-cell; the former quantity was corrected for the slightly greater area of the lunar surface. We also computed lunar heat flow values for increased radioactive abundances, keeping unchanged all other parameters. One of these values is also listed in the table.

TABLE I

A summary of the original and new heat flow values

\begin{tabular}{|c|c|c|c|c|c|}
\hline \multirow{2}{*}{$\begin{array}{l}\text { Figure No. } \\
\text { (in orig. } \\
\text { paper) }\end{array}$} & \multirow{2}{*}{$\begin{array}{l}\text { Original } \\
\text { heat flux } \\
\text { (erg cm }{ }^{2}-\mathrm{s}^{-1} \text { ) }\end{array}$} & \multicolumn{4}{|l|}{ New Calculations } \\
\hline & & $\begin{array}{l}\text { U concentration } \\
\left(10^{-8} \mathrm{~g} / \mathrm{g}\right)\end{array}$ & $\begin{array}{l}\text { Heat flux } \\
\text { (erg cm}{ }^{2}-\mathrm{s}^{-1} \text { ) }\end{array}$ & $\begin{array}{l}U \text { concentration } \\
\left(10^{-8} \mathrm{~g} / \mathrm{g}\right)\end{array}$ & $\begin{array}{l}\text { Heat flux } \\
\left.\text { (erg } \mathrm{cm}^{-2}-\mathrm{s}^{-1}\right)\end{array}$ \\
\hline 5 & 24 & 2.3 & 12 & - & - \\
\hline 7 & 25 & 2.3 & 15 & 4.6 & 26 \\
\hline 8 & 27 & 2.3 & 16 & - & $\ldots$ \\
\hline 9 & 29 & 2.3 & 15 & - & - \\
\hline 10 & 25 & 2.3 & 14 & - & - \\
\hline 11 & 21 & 1.1 & 8 & - & - \\
\hline 12 & 25 & 2.3 & 13 & - & - \\
\hline
\end{tabular}

The temperature curves given in the original paper (Figures 4, 5, 7, 8, 9, 10, 11, 12) are correct for the stated radio-activity. For a model with twice the radioactive abundance (average present-day concentration of uranium $=4.6 \times 10^{-8} \mathrm{~g} / \mathrm{g} ; \mathrm{Th} / \mathrm{U}=$ $=4.0$, and $\mathrm{K} / \mathrm{U}=2000$ ) the present-day temperature profiles are higher by about $50^{\circ}$ at a depth of $100 \mathrm{~km}$ and by less than $200^{\circ} \mathrm{C}$ in the deep lunar interior.

On the basis of these new calculations, we can state that for the type of evolution models we considered, it is necessary to have at least $6 \times 10^{-8} \mathrm{~g} / \mathrm{g}$ present-day average uranium abundance in order to match the lunar surface heat flux measured at the Apollo 15 site in the Apennine-Hadley region. Such a model does not violate any of the constraints stated in our paper. The differentiation and/or enrichment of radioactive heat sources toward the surface at early stages of lunar evolution is a require- 
ment in all these models in order to prevent extensive melting in the lunar interior at the present and to fit surface values of radioactivity.

We thank J. F. Hays, T. C. Hanks, and L. Thomsen for pointing out to us the likelihood that our original heat flow values might have been in error. 